\title{
Human Capital and Relational Capital on University Quality with Environmental Uncertainty as Moderating Variables (Evidence in Java Island-Indonesia)
}

\author{
Nurul Hidayaha, Lucky Nugroho $^{b}$, Hendi Prihanto ${ }^{c}$ \\ a Universitas Mercu Buana, Indonesia, nurul.hidayah@mercubuana.ac.id, https://orcid.org/0000-0002-0680-5681 \\ ${ }^{b}$ Universitas Mercu Buana, Indonesia, lucky.nugroho@mercubuana.ac.id, https://orcid.org/0000-0002-9613-1667 \\ c Universitas Moestopo Beragama, Indonesia, hendiprihanto@dsn.moestopo.ac.id, https://orcid.org/0000-0002-13020348
}

\section{ARTICLE INFO}

\section{Research Article}

2020, Vol. 3(3), 164-182

e-ISSN 2667-5927

Article History:

Received: 03.04.2021

Revised: 30.04 .2021

Accepted: 30.04 .2021

Available Online: 25.07.2021

JEL Code: C33, C36, 016

Keywords: human capital, relational capital, environmental uncertainty, university quality, education
Human Capital and Relational Capital on University Quality with Environmental Uncertainty as Moderating Variables (Evidence in Java Island-Indonesia)

Abstract

Universities must face environmental uncertainty, which includes internal uncertainty and external uncertainty, which is very difficult for universities to predict and threatens the university's sustainability. This research aims to prove the effect of human capital and relational capital on university quality and environmental uncertainty that can affect university quality. The method used in this research is multiple regression, using purposive sampling and primary data in an online questionnaire. This study concluded that human capital and relational capital affect quality, and environmental uncertainty does not moderate the influence of human capital and relational capital variables on university quality. This research's contribution provides additional insight and input on the importance of human capital and relational capital in improving quality and the need to anticipate the external environment's uncertainty.

To cite this document: Okezıe, C.R. \& Kanu, I. M. \& Iwu, C. C.( 2021). Social Capital and Loan Repayment Capacity of Agripreneurial Groups' in Abia State, Nigeria. BILTURK, The Journal of Economics and Related Studies, 3(3), 117-132. doi: 10.47103/bilturk.908864. 


\section{Introduction}

Higher education quality is measured using the quality dimension of human resources, namely lecturers, students, and educational staff. The quality of higher education is an agenda in determining the Ministry of Research, Technology, and Higher Education strategy from 2015 to 2019, aiming to improve the quality of higher education (Hendayana, 2020). The strategy carried out by the government to create excellence and competitiveness is carried out by increasing the quality of human resources, which are human capital for the university (Kucharčíková, Tokarčíková, \& Blašková, 2015). Improving the quality of human resources (students, lecturers, and education staff) is carried out through competency enhancement, improving the university's quality (Hill, Lomas, \& Macgregor, 2003). Regarding the quality of human resources, Wahyudin \& Suwirta (2020) explains that the cause of the not optimal quality of education in Indonesia is seen by domestic university graduates' inability to compete with foreign university graduates. The inability of higher education to compete in the labor market requires the role of the government. Through the Ministry of Research, Technology, and Higher Education, the government's role encourage universities to improve quality by providing material and non-material assistance. Material assistance in the form of an Education fund 20\% of the government expenditure budget of 2019 is used to improve human resources quality (Sukmana \& Jatmiko, 2019). The government also conducts university rankings as a step to encourage improvement in university quality. This ranking is a trend both among universities in the country but universities abroad.

Altbach \& Hazelkorn (2018) reveal the trend of global ranking or universities' world to be a solution that can be recognized as an indicator of university quality. In Indonesia, the policy taken by the government through the ministry of research and higher education technology determines the ranking of universities based on the QS World University Ranking as the official reference for world university rankings to encourage universities in Indonesia to become involved and become one of the universities that have world quality. However, the universities referred to are only state universities such as the University of Indonesia (UI), the Bandung Institute of Technology (ITB), Gadjah Mada University (UGM), and other public universities. These universities are expected to be able to compete with other universities abroad. In 2017 for the first time, UI was ranked 277th, and ITB ranked 331st and was followed by other public Universities.

The university's quality is inseparable from the stakeholders' role, for that the university must always establish good relations by collaborating in the academic and non-academic fields. The Triple Helix concept, which describes a good relationship between university-industry-government, is intended to develop 
public knowledge. Triple Helix assumes that the potential for creating innovation and economic development of society through knowledge lies in the more prominent role of the university and the combination of elements from university, industry, and government to produce institutional and social formats for producing, transferring, and applying knowledge (Fischer et al., 2018; Laursen, Reichstein, \& Salter, 2011). The relationship between the university, industry, and government, which is a relational capital, can improve the university's quality and create a competitive advantage through innovation. Lee \& Ngo (2012) explain that the triple helix, which is the relationship between university-industry and government by using and utilizing knowledge aimed at developing society, is essential in an environment of global competition.

The Kemenristekdikti (education ministry of Indonesia), annually announces the ranking of universities in Indonesia, both public and private. In general, in the top 100 rankings, public universities still dominate compared to private universities. There are still many private universities that are left behind and only occupy the lower ranking. This is because private universities have their own goals, missions, and uniqueness. Higher education rankings often override this and consider all universities to be the same so that they are assessed in the same way, whether large public universities or private universities. The diversity of universities rarely gets space and attention. Private universities are inevitably forced to match a specific institutional model, universities with the best ranking, while universities with characters that are not in line with the ranking's focus will be eliminated.

The Kemenristekdikti annually announces the ranking of universities in Indonesia, both public and private. In general, in the top 100 rankings, public universities still dominate compared to private universities. There are still many private universities left behind and only occupy a lower ranking than public universities (Rahayu, 2011). This is because private universities have a purpose, mission, and uniqueness according to their needs and desires. Higher education ranking often overrides this uniqueness and considers all universities to be the same. It is assessed by the same good aspects between public universities and private universities. The diversity of universities rarely gets space and attention. Private universities are inevitably forced to adjust the public university model with the best ranking, while universities with aspects that are not in line with the focus will be eliminated.

Private universities still have a lot to catch up with to achieve better quality and equal public universities. The indicators required in ranking universities, especially universities, are the quality of human resources, the quality of management, the quality of student activities, and the quality of research and publications. All tertiary institutions in Indonesia must meet these four requirements. The quality of human resources is a significant concern for universities must be able to manage them properly. Anwar UI Haq et al. (2020) explained that intellectual capital through quality human resources proxies significantly affects higher education quality. 
Human resources are intellectual capital that has a role in improving the quality and competitiveness of the organization.

Furthermore, intellectual capital makes universities focus on managing their resources so that they can survive in a rapidly changing knowledge-based environment (Muhammad, 2016). Intellectual capital is significant in creating value and maintaining a competitive advantage (Jardon \& Martos, 2012). Public and private sector organizations pay attention to their primary activity and must be able to adapt to the development of knowledge and innovation as a source of sustainable excellence (Bontis, 2001). Also, to survive in a competitive environment, universities must have the intellectual capital to achieve the goal of creating knowledge that can increase their competitive advantage (Marti, 2004). According to Ramírez \& Gordillo (2014), the intangible elements that are very important and must be measured are capitalized in the academic profession and teaching capabilities. Apart from human capital, relational capital is also significant and must be measured through graduates who are already working, student satisfaction, and the university's relationship with industry (Hormiga, BatistaCanino, \& Sánchez-Medina, 2011).

Furthermore, relational capital benefits the university, including students and parents, as consumers provide feedback regarding service quality to contribute to its reputation. Cooperation between universities and industry, which is explicitly realized through a contract of understanding, will benefit both parties in regulating the supply of resources. Meanwhile, cooperation with the government is needed by the university (Guo \& Zhuang, 2018).

In addition to adequate and continuously developing human capital and relationship capital, universities are required to take advantage of their ability to see and use opportunities, identify problems, select solutions to problems, and adapt to environmental changes (Nugroho et al., 2017). Environmental changes that create uncertainty will make it difficult for university leaders to predict the future, make it difficult to make plans and policies. If they cannot understand the state of the environment, they must anticipate environmental uncertainty in the form of changes in government regulations and advances in information and communication technology (Nugroho et al., 2020). The problem of environmental uncertainty is indicated by the lack of universities in responding to changes. Environmental uncertainty also occurs in Indonesia's universities that do not respond to environmental changes externally and internally. Changes in the technological environment and innovation, and economic globalization require universities to respond to changes (Altbach \& Hazelkorn, 2018). Previous research to examine the effect of human capital and relational capital on university quality has been widely conducted. Still, the moderating effect of environmental uncertainty is rare. Chatterji \& Kiran (2017) concluded that human capital affects 
university quality by achieving good performance. Al-Tahat, Matarneh, \& Moneim Ali (2019) argued that intellectual capital, which consists of human capital, relational capital, and structural capital, affects the university's quality. Another study by Nir \& Sharma Kafle (2013) concluded that political stability affects university quality in several countries. From the description above, the question is whether it is true that human capital and relational capital affect university quality, while environmental uncertainty moderates the influence of these two variables.

\section{Literature Review}

\subsection{Total Quality Management}

Rad (2006) defines Total Quality Management as a concept in which all organizational managers are committed and involved to fulfill customer desires or satisfaction on an ongoing basis. Total Quality Management is a system that improves quality (Kanji, 1996). One of the quality management programs is Total Quality Management which is an integrated management philosophy that can be applied flexibly in public and private organizations through the improvement of a sustainable performance culture where a successful organization continuously strives to improve the quality of products or services to meet perceptions, expectations, as well as customer satisfaction (Imran et al., 2019; Mahliza et al., 2020). However, Total Quality Management is an integrated effort of an organization in achieving and maintaining high-quality products and or services by carrying out maintenance, system repair, and continuous error prevention processes at all levels and functions within the organization to fulfill needs that exceed customer expectations (Gimenez-Espin, Jiménez-Jiménez, \& MartínezCosta, 2013).

\subsection{Human Capital and University Quality}

Human Capital is an intangible resource that employees provide to the organization. Bontis (2001) defines human capital as representing the human factor in an organization that combines intelligence, skills, and expertise that gives the organization its character. The human element of organizations can learn, change, innovate, and provide creative encouragement. Moreover, if human capital is adequately motivated, it will ensure the organization's long-term sustainability (Gambardella, Panico, \& Valentini, 2015). Human capital is not owned by the organization but is obtained through working relationships with employees (Lepak \& Snell, 2002). Human capital will impact organizations because they have competency through experience and training (Lim, Chan, \& Dallimore, 2010). Also, according to Secundo et al. (2017), there are three critical activities to improve the quality of higher education: (i) The teaching process, (ii) Research quality, and (iii) Innovation activities (intellectual capital). Intellectual capital will increase the university's competitiveness and stimulate innovation by transferring knowledge and technology to the industry. 
Human capital, which is part of the university's intellectual capital, consists of students, lecturers, and academic staff (Vodenko \& Lyausheva, 2020). These three elements have an essential role in improving the quality of the university. Furthermore, the Kemenristekdikti policy is that to achieve SDGs (Sustainable Competitive Goals), one must improve the quality of highly educated human resources. The strategic goal that needs to be done is to improve the university's quality by improving the quality of learning and lecturer competence, the number of lecturers with doctoral degrees, and the number of researches (Lessing \& Schulze, 2004). Therefore, human capital is significant and influences the university's quality (Islam et al., 2016). Moreover, Grange (2011) concluded that human capital significantly affects universities' quality through education investment. The best quality of graduates from tertiary institutions will contribute to progress in all industries and further impact economic growth.

\subsection{Relational Capital and University Quality}

Bontis (2006) states that relational capital is all sources associated with external parties in the business, such as customers, suppliers, and partners in research and development. Relational capital in which human capital and structural capital are interrelated in business activities with outside stakeholders. Mtawa et al. (2016), Universities can improve their quality by optimizing relational capital where the more they collaborate with the community, the better the university's quality. There is a triple helix-based cooperation model, namely the interaction between universities, government, and industry to develop knowledge (Zhou, 2008). Furthermore, according to Secundo et al. (2017), the elements of relational capital use indicators (i) Academic collaboration with outsiders in transferring technology and knowledge; (ii) Developing university networks through cooperation with strategic industries.

Stephen M. Nowlis \& Simonson (1996) argue that quality is the totality of features and characteristics of a product or service that can satisfy customer needs. Murias et al. (2008) define quality in higher education as consisting of three points of view. First, in terms of functionality, where the quality of higher education is defined as the harmony between the results and the general goals of higher education. Second, in terms of effectiveness, quality is defined as the harmony between the results and the activity's specific objectives. The third is the harmony between the results with the input and the process in terms of efficiency. Moreover, according to Jørgensen et al. (2006), a university's systematic quality improvement includes developing a management plan, continuous quality improvement, and delegating responsibility for quality improvement related to integrated management.

One of the government's strategies to improve the universities' quality is by establishing good relations between universities, industry, and the government, 
Hidayaha, N., Nugrohob L. \& Prihantoc H. (2021). Human Capital and Relational Capital on University Quality with Environmental Uncertainty as Moderating Variables (Evidence in Java Island-Indonesia), BILTURK, The Journal of Economics and Related Studies, 3(3), 164-182. . doi: 10.47103/bilturk.908864.

known as the Triple Helix. Triple Helix is a relational capital that the university carries out to improve its quality by developing a knowledge-based society. According to Lee \& Ngo (2012) and Zhou (2008), Universities need to make synergies and collaborations with industry to support economic development and the growth of science, business organization, and funding. Research conducted by Chatterji \& Kiran (2017) concluded that relational capital is an essential factor that strengthens human capital's influence on university performance. Nevertheless, to achieve the goals that have been set, universities must be supported by substantial human capital and relational capital. Moreover, human capital and relational capital will help policymakers face the global shift towards the knowledge economy.

\subsection{Environmental Uncertainty and University Quality}

Environmental uncertainty is management's inability to predict the future because management does not have sufficient information about the organization's environment to predict the future Duncan (1972). Similar to Milliken (1987), the phenomenon of uncertainty has long occurred in life and affects choices and decision making. This uncertainty occurs because of a lack of understanding and facing uncertainty in organizational decision-making caused by adverse effects, missed opportunities, and inappropriate results (Abbott, 2005).

Environmental uncertainty is a factor that affects performance if the organization is unable to predict and adapt to environmental changes. Universities with good capital will be able to deal with this uncertainty (Wang et al., 2017), concluding that an organization will have a competitive advantage if facing environmental uncertainty and anticipating it by utilizing resources optimally. When the company's routine is no longer as expected, it will erode the competitive advantage. Moreover, the organization must be of quality by utilizing its intellectual capital, such as human capital. Nir \& Sharma Kafle (2013) concluded that environmental uncertainty due to political stability impacts the quality of education in 47 countries where 26 are politically stable and 21 are politically unstable. The results showed that political stability had a significant effect on the quality of education. Education was the country's primary concern, primarily through improving the quality of human resources.

Sudirman et al. (2020) and Bennett \& Lemoine (2014) explain that the ability to apply information technology in anticipating the era of volatility, uncertainty, complexity, ambiguity (VUCA) is an effort to deal with environmental uncertainty. Furthermore, the ability to apply information technology will encourage sustainability in facing challenges. Quality tertiary institutions that pay attention to learning and research are a stimulus for economic development and growth. Higher education must then work together by collaborating with industry. Moreover, Meissner \& Wulf (2014) concluded that uncertainty affects organizational quality. Therefore, it is necessary to maintain good relationships with customers. Also, 
Hidayaha, N., Nugrohob L. \& Prihantoc H. (2021). Human Capital and Relational Capital on University Quality with Environmental Uncertainty as Moderating Variables (Evidence in Java Island-Indonesia), BILTURK, The Journal of Economics and Related Studies, 3(3), 164-182. . doi: 10.47103/bilturk.908864.

uncertainty has a negative effect on the quality of the organization, so it needs adaptation, cooperation, communication, commitment, and trust

\subsection{Conceptual Framework and Hypothesis}

The conceptual framework in research refers to the background and literature review as follows:

Figure 1: Conceptual Framework

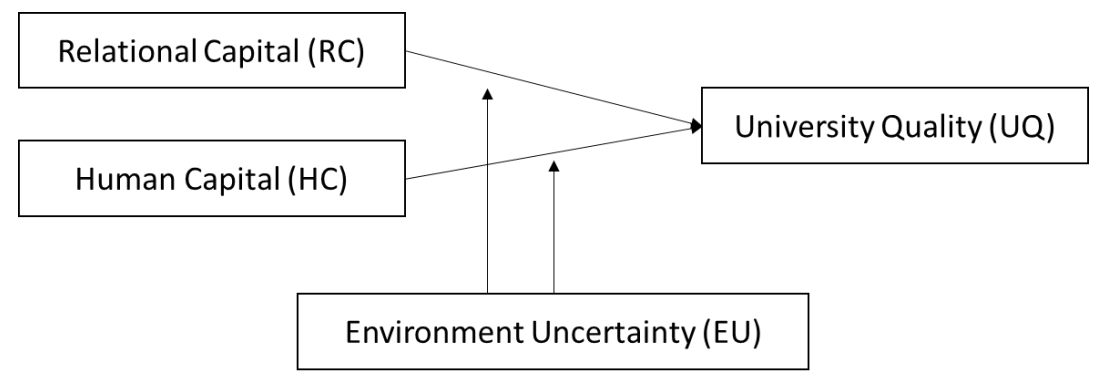

Referring to Figure 1 above, the hypothesis in this study is as follows:

- Ha1: There is an effect of human capital on the quality of the university;

- Ha2: There is an effect of relational capital on the quality of the university;

- Ha3: Environmental Uncertainty moderates the influence of human capital on the quality of the University;

- Ha4: Environmental Uncertainty moderates the effect of relational capital on the quality of the University.

\section{Methodology}

This research uses descriptive and explanatory causal methods to test one variable that causes changes in other variables. The design in this study begins with a problem in the form of a phenomenon and then formulates its problem. To obtain research results that are following the objectives and represent the circumstances and the number of samples available, the researchers conducted the sampling technique used in this study with the simple random technique. This study population was private universities on the island of Java, as many as 319 private universities. The reason for selecting the sample in Java is that the number of universities in Java is the largest populated island in Indonesia. The research instrument testing was carried out using SEM-PLS to test the validity, reliability (outer model), and hypothesis testing (inner model). 


\section{Results and Discussion}

Testing the Outer Model for each construct research variable is intended to determine the data's validity and reliability. The convergent Validity test for each reflexive indicator is considered valid if it has a loading factor value that meets the requirements above 0.7 , which means that each variable's indicator is considered to have good validity or meet the suitability requirements above 0.70 . However, at the research stage of scale development, the load factor above 0.50 to 0.60 is still acceptable (Ghozali, 2013). Furthermore, the reliability test was carried out on the research variables' constructs by measuring two criteria: composite reliability and Cronbach alpha. The research variable construct is declared reliable if the composite reliability and Cronbach alpha values are above 0.70 (Ghozali \& Latan, 2015). The following are the results of data processing with the Outer Model as follows:

\section{Figure 2: Test Construct Validity}

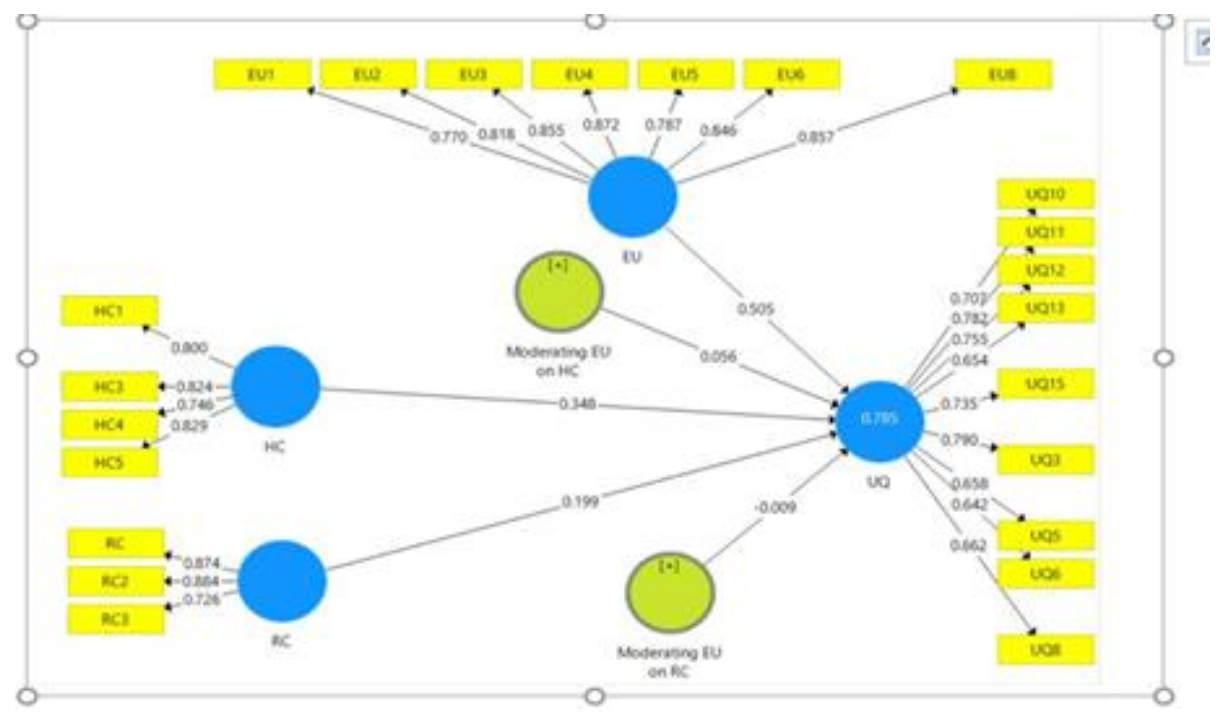

Testing the Outer Model for each construct research variable is intended to determine the data's validity and reliability. The convergent Validity test for each reflexive indicator is considered valid if it has a loading factor value that meets the requirements above 0.7 , which means that each variable's indicator is considered to have good validity or meet the suitability requirements above 0.70 . Furthermore, According to the test results above (figure 2), all the constructs of the research variables of human capital $(\mathrm{HC})$, relational capital $(\mathrm{RC})$, environmental uncertainty (EU), and university quality (UQ) have met the validity requirements because they are at a level above 0.5. Furthermore, the outer model test is related to the research construct's reliability by looking at the value of Cronbach's Alpha, Composite Reliability, and Average Variance Extracted (EVA). As in the table below (Table 6.1), all research variables meet the requirements for CA (Cronbach's Alpha), which is above 0.7 , CR (Composite Reliability), which is also above 0.7 . 
Table 1: Reliability Test Results

\begin{tabular}{|c|c|c|c|c|}
\hline \multicolumn{5}{|c|}{ Construct Reliability and Validity } \\
\hline & Cronbach's & rho_A & Composite & Average Variance \\
\hline & Alpha & & Reliability & Extracted (AVE) \\
\hline EU & 0.924 & 0.926 & 0.939 & 0.689 \\
\hline $\mathrm{HC}$ & 0.814 & 0.833 & 0.877 & 0.641 \\
\hline Moderating & 1.000 & 1.000 & 1.000 & 1.000 \\
\hline \multicolumn{5}{|l|}{ EU on $\mathrm{HC}$} \\
\hline Moderating & 1.000 & 1.000 & 1.000 & 1.000 \\
\hline \multicolumn{5}{|l|}{ EU on RC } \\
\hline $\mathrm{RC}$ & 0.772 & 0.784 & 0.869 & 0.691 \\
\hline UQ & 0.877 & 0.882 & 0.902 & 0.506 \\
\hline
\end{tabular}

Furthermore, the $\mathrm{R}$ Square test is carried out where the $\mathrm{R}$ Square test is a test carried out to see the R-square value, which is a goodness-fit model test, which means that the model used in the study is fit or appropriate, that can see it in the $\mathrm{R}$ Square test table (table 2).

Table 2: R Square Test Results

\begin{tabular}{|l|c|c|c|c|c|}
\hline Total Effects & & & & & \\
\hline & Original Sample (O) & Sample Mean (M) & Standard Deviation & T Statistics & P Values \\
\hline EU $\rightarrow$ UQ & 0.505 & 0.506 & 0.065 & 7.771 & 0.000 \\
\hline HC $\rightarrow$ UQ & 0.348 & 0.349 & 0.056 & 6.258 & 0.000 \\
\hline Moderating Effect 1 -> UQ & 0.056 & 0.056 & 0.040 & 1.393 & 0.164 \\
\hline Moderating Effect 2 -> UQ & -0.009 & -0.011 & 0.039 & 0.226 & 0.821 \\
\hline RC $\rightarrow$ UQ & 0.199 & 0.199 & 0.083 & 2.394 & 0.017 \\
\hline & & & & & \\
\hline
\end{tabular}

Table 2 above shows that the variables Human Capital and Relational Capital have a significant effect on University Quality. However, Environmental Uncertainty is proven to not moderate, namely weakening or strengthening Human Capital and Relational Capital's influence on University Quality.

The results of research data processing show that human capital significantly affects the university's quality. This means that the increasing use of human capital in academic activities will further improve its quality. The private universities that become respondents understand very well and are aware of every indicator of human capital, namely knowledge, competence, lecturer experience as measured by the number of lecturers with doctoral education, and the number of lecturers who have associate professors. Human capital includes the number of lecturers who have educator certification and who have experience as resource persons or guest lecturers at other universities. These human capital indicators have a 
significant effect on the quality of the university. This is following the criteria in the accreditation or ranking requirements based on university clusterization. Likewise, the skills possessed by educational personnel will improve the quality of academic and non-academic services. This research is following the theoretical concept of Gimenez-Espin et al. (2013), improving the quality of products and services of an organization or in this study, it is necessary to continue to carry out improvement in every function of the organization, where is the quality of human resources as the primary factor (Medsker, 1994).

Moreover, board management commitment and involvement also essential to support the human capital to impact the improvement of organization function (Carpenter et al., 2001). This study is in line with the research of Grange (2011) that human capital is significantly affecting the quality of universities through investment in education. Barbosa et al. (2016) state that human capital affects the quality of higher education, and it is a vital variable as a source of knowledge to improve the quality of human resources following the SDGs (Sustainable Development Goals), namely improving the quality of highly educated human resources through strategic goals of improving the quality of learning. This study is not in line with Mondal et al. (2012), who concluded that capital (human capital, structural capital, and relational capital) does not affect organizational quality.

Relational Capital in this study has a positive effect on the quality of the university. Universities that have relationships with other partners, both by the government, industry, and other universities (Triple Helix), will affect quality improvement by increasing collaborations, which will directly increase research or cooperation domestically and abroad. Regulation of the Minister of Education of the Republic of Indonesia No. 14 of 2014 states that cooperation between domestic universities and foreign universities will improve the university's quality. The implementation of this collaboration must be accompanied by proof of a Letter of Intent, Memorandum of Understanding, and Memorandum of Agreement documents. The implementation can include student exchanges, guest lecturers, and research collaboration. The existence of foreign cooperation carried out by private universities will impact the chances of accepting international students and the achievement of internationally accredited study programs. Also, that can realize cooperation between private universities and government, and industry through the recruitment of graduates to become employees or apprentices. Collaboration with external parties allows study programs to have a curriculum that is in line with industry demand. The results of this study are under the theoretical concept of Gazperz, Vincent (2008) that universities must focus on four factors, namely: (i) the needs of the labor market, (ii) a dynamic and market-oriented educational process, (iii) a controlled learning process (iv) produce competitive graduates. The implementation of these four factors can be accelerated if there is cooperation with the various parties. 
Environmental uncertainty is a condition faced by universities due to universities' inability to predict changes in the external environment (Utami et al., 2020a). The function of predicting the external environment is to analyze the impacts of these changes and anticipate them (Utami et al., 2020b). The study results concluded that it turns out that environmental uncertainty does not moderate the influence of human capital on the quality of the university. The uncertainty of the external environment caused by external environmental factors is due to government regulations and policies. The impact of these regulations and policies causes the university to follow every new regulation or policy by utilizing human capital. However, not all universities can adjust due to the limitations of their human capital (Chatterji \& Kiran, 2017). Likewise, the impact of technological changes because of their general nature must be followed by all stakeholders from tertiary institutions, such as online lectures carried out by lecturers and students during the Covid-19 Pandemic. Furthermore, almost all private universities are doing so. This study's results are not in line with Wang et al. (2017), who concluded that a quality organization would be able to deal with and anticipate environmental uncertainty by utilizing human capital. Nir \& Sharma Kafle (2013) concluded that environmental uncertainty due to political instability impacts the quality of education, including human capital, which plays a role in producing university excellence.

The university's relational capital, manifested by establishing relationships in the form of cooperation carried out by universities with external parties such as the government, industry, and other universities do not affect its quality, moderated by environmental uncertainty. Uncertainty in the future that will affect the university's sustainability has begun to be anticipated by the university's strategies by utilizing its relational capital (Paoloni et al., 2019). Through cooperation with external parties (stakeholders), the university will have much information to anticipate this uncertainty's impact. Still, it will not improve the university's quality if it does not pay attention to the importance of cooperation. This research is in line with Leonidou et al. (2006), concluding that environmental uncertainty reduces the university's quality. Therefore, the steps that must take are establishing good relationships with outsiders, the need for adaptation, and increasing communication, commitment, and trust.

\section{Conclusion}

The results showed that the quality of private universities in Indonesia was quite good. In this study, two hypotheses have no significant effect: the human capital variable and the relational capital variable in university quality, moderated by the environmental uncertainty variable. Meanwhile, the variables of human capital and relational capital directly affect the university's quality. 
Human Capital has a significant effect on the quality of the university. Human resources improve the quality of a tertiary institution, where human resources consisting of indicators of knowledge, attitudes, competencies, and experiences of lecturers and teaching skills significantly affect the quality of higher education. Furthermore, improving the quality of services, improving the quality of learning, the quality of publications and research, and community service activities have implications for the university's excellent ranking.

University Relational Capital, as measured by the indicators of the network development process and academic collaboration, has a significant impact on improving the quality of the university. The management of the university must have the ability to establish academic cooperation with other universities. The form of cooperation can be in research collaboration, student exchanges, and guest lecturers. Furthermore, university management must collaborate with industry and government players, such as providing internships or placing graduates who are accepted to work, significantly impacting university performance. Also, it can have a significant impact on the reputation of the university so that it becomes a reference for prospective students.

Human Resources, which are moderated by environmental uncertainty variables, do not affect the university's quality. This is due to the uncertainty of the external environment that universities will face in the future, such as changes in regulations or government policies and technology changes that can be anticipated and mitigated by higher education management through policies and programs that regulators have previously informed. Thus, the university can mitigate and anticipate future changes with its human resources and the university's relational capital. 


\section{References}

Abbott, J. (2005). Understanding and managing the unknown the nature of uncertainty in planning. Journal of Planning Education and Research, 24(3), 237251. https://doi.org/10.1177/0739456X04267710

Al-Tahat, S. S., Matarneh, A. J., \& Moneim Ali, O. A. (2019). The Impact of the Intellectual Capital of the University Administration in Achieving the Quality of Education. International Journal of Economics and Finance, 11(2), 137. https://doi.org/10.5539/ijef.v11n2p137

Altbach, P. G., \& Hazelkorn, E. (2018). Measuring Education Quality in Global Rankings: What's the Likelihood? International Higher Education, (95), 12-14. https://doi.org/10.6017/ihe.2018.95.10721

Anwar UI Haq, Sadaf Mahmood, Zahira Batool, \& Muhammad Shabbir. (2020). Grade Inflation and Human Capital Accumulation among Pakistani University Students. Journal of Accounting and Finance in Emerging Economies, 6(3), 747-751. https://doi.org/10.26710/jafee.v6i3.1360

Barbosa, S., Vale, J., Teixeira Vale, V., \& Castelo Branco, M. (2016). Intellectual Capital and Performance in Higher Education Organizations. In Proceedings of the International Conference Theory and Applications in the Knowledge Economy (TAKE) 2016 (pp. 670-681).

Bennett, N., \& Lemoine, G. J. (2014). What a difference a word makes: Understanding threats to performance in a VUCA world. Business Horizons, 57(3), 311-317. https://doi.org/10.1016/j.bushor.2014.01.001

Bontis, N. (2001). Assessing Knowledge Asset: A Review of the Models Used to Measure Intellectual Capital. International Journal of Management Reviews, 3(1), 41-60.

Bontis, N. (2006). Managing organisational knowledge by diagnosing intellectual capital: framing and advancing the state of the field. International Journal of Technology Management, 18(5/6/7/8), 433. https://doi.org/10.1504/ijtm.1999.002780

Carpenter, M. A., Sanders, W. M. G., \& Gregersen, H. A. L. B. (2001). Bundling Human Capital with Organizational Context: The Impact of International Assignment Experience on Multinational Firm Performance and CEO Pay. Academy of Management Journal, 44(3), 493-511. Retrieved from http://10.0.9.3/3069366\%5Cnhttp://search.ebscohost.com/login.aspx?direct=tru

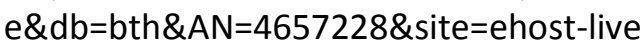

Chatterji, N., \& Kiran, R. (2017). Role of human and relational capital of universities 
as underpinnings of a knowledge economy: A structural modelling perspective from north Indian universities. International Journal of Educational Development, 56(August 2016), 52-61. https://doi.org/10.1016/j.ijedudev.2017.06.004

Duncan, R. B. (1972). Characteristics of Organizational Environments and Perceived Environmental Uncertainty. Administrative Science Quarterly, 17(3), 313. https://doi.org/10.2307/2392145

Fischer, B. B., Schaeffer, P. R., Vonortas, N. S., \& Queiroz, S. (2018). Quality comes first: university-industry collaboration as a source of academic entrepreneurship in a developing country. Journal of Technology Transfer, 43(2), 263-284. https://doi.org/10.1007/s10961-017-9568-x

Gambardella, A., Panico, C., \& Valentini, G. (2015). Strategic incentives to human capital. Strategic Management Journal, 36(1), 37-52. https://doi.org/10.1002/smj.2200

Ghozali, I. (2013). Aplikasi Analisis Multivariate dengan Program IBM SPSS 21 Update PLS Regresi. Semarang: Undip Press.

Ghozali, I., \& Latan, H. (2015). Partial Least Square, Konsep Teknik, dan Aplikasi menggunakan program SmartPLS 3.0 untuk Penelitian Empiris. Semarang: Undip Press.

Gimenez-Espin, J. A., Jiménez-Jiménez, D., \& Martínez-Costa, M. (2013). Organizational culture for total quality management. Total Quality Management and Business Excellence, 24(5-6), 678-692. https://doi.org/10.1080/14783363.2012.707409

Grange, L. Le. (2011). Human Capital, (Human) Capabilities and Higher Education. South African Journal of Higher Education, 25(6), 1039-1046.

Guo, N., \& Zhuang, J. (2018). Practice and exploration of "cooperative education" from the perspective of the symbiosis theory. In 7th International Conference on Energy, Environment and Sustainable Development (ICEESD 2018) (Vol. 163, pp. 2934). https://doi.org/10.2991/iceesd-18.2018.6

Hendayana, Y. (2020). Ditjen Dikti Dorong Agenda _World Class Professor_untuk Meningkatkan Kualitas Publikasi dan Pengembangan Teknologi - Direktorat Jenderal Pendidikan Tinggi Kementerian Pendidikan dan Kebudayaan Republik Indonesia. Retrieved March 17, 2021, from https://dikti.kemdikbud.go.id/kabardikti/kabar/ditjen-dikti-dorong-agenda-_world-class-professor_-untukmeningkatkan-kualitas-publikasi-dan-pengembangan-teknologi/

Hill, Y., Lomas, L., \& Macgregor, J. (2003). Students' perceptions of quality in higher education. Quality Assurance in Education, 11(1), 15-20. https://doi.org/10.1108/09684880310462047

Hormiga, E., Batista-Canino, R. M., \& Sánchez-Medina, A. (2011). The Impact of Relational Capital on the Success of New Business Start-Ups. Journal of Small 
Business Management, 49(4), 617-638. https://doi.org/10.1111/j.1540627X.2011.00339.X

Imran, M., Raziq, A., Khaliq, M., \& Saleem, H. M. N. (2019). The Influence of Total Quality Management and Export Market Orientation on company export performance of Furniture Industry in Pakistan: A moderating role of Business Network. In Third International Conference On Economics Education, Economics, Business and Management, Accounting and Entrepreneurship (PICEEBA 2019) (Vol. 97, pp. 499-516). https://doi.org/10.2991/piceeba-19.2019.56

Islam, R., Ghani, A. B. A., Kusuma, B., \& Theseira, B. B. (2016). Education and human capital effect on Malaysian economic growth. International Journal of Economics and Financial Issues, 6(4), 1722-1728.

Jardon, C. M., \& Martos, M. S. (2012). Intellectual capital as competitive advantage in emerging clusters in Latin America. Journal of Intellectual Capital, 13(4), 462481. https://doi.org/10.1108/14691931211276098

Kanji, G. K. (1996). Implementation and pitfalls of total quality management. Total Quality Management, 7(3), 331-343. https://doi.org/10.1080/09544129650034882

Kucharčíková, A., Tokarčíková, E., \& Blašková, M. (2015). Human Capital Management - Aspect of the Human Capital Efficiency in University Education. In Procedia - Social and Behavioral Sciences (Vol. 177, pp. 48-60). https://doi.org/10.1016/j.sbspro.2015.02.332

Laursen, K., Reichstein, T., \& Salter, A. (2011). Exploring the Effect of Geographical Proximity and University Quality on University-Industry Collaboration in the United Kingdom. Regional Studies, 45(4), 507-523. https://doi.org/10.1080/00343400903401618

Lee, S. J., \& Ngo, T. H. (2012). Riccardo Viale and Henry Etzkowitz (eds): The capitalization of knowledge: a triple helix of university-industry-government. Higher Education, 63(1), 161-163. https://doi.org/10.1007/s10734-011-9427-x

Leonidou, L. C., Barnes, B. R., \& Talias, M. A. (2006). Exporter-importer relationship quality: The inhibiting role of uncertainty, distance, and conflict. Industrial Marketing Management, 35(5), 576-588. https://doi.org/10.1016/j.indmarman.2005.06.012

Lepak, D. P., \& Snell, S. A. (2002). Examining the human resource architecture: The relationships among human capital, employment, and human resource configurations. Journal of Management, 28(4), 517-543. https://doi.org/10.1016/S0149-2063(02)00142-3 
Hidayaha, N., Nugrohob L. \& Prihantoc H. (2021). Human Capital and Relational Capital on University Quality with Environmental Uncertainty as Moderating Variables (Evidence in Java Island-Indonesia), BILTURK, The Journal of Economics and Related Studies, 3(3), 164-182. . doi: 10.47103/bilturk.908864.

Lessing, A., \& Schulze, S. (2004). Lecturers' experience of postgraduate supervision in a distance education context. South African Journal of Higher Education, 17(2), 159-168. https://doi.org/10.4314/sajhe.v17i2.25309

Lim, L. L. K., Chan, C. C. A., \& Dallimore, P. (2010). Perceptions of Human Capital Measures: From Corporate Executives and Investors. Journal of Business and Psychology, 25(4), 673-688. https://doi.org/10.1007/s10869-009-9150-0

Mahliza, F., Nugroho, L., \& Ali, A. J. (2020). Antecedents and Consequences of Muslim Millennials Attitude Towards Halal Personal Care Products. IKONOMIKA, 5(2), 249-270. https://doi.org/10.24042/febi.v5i2.7203

Marti, J. M. V. (2004). Social capital benchmarking system: Profiting from social capital when building network organizations. Journal of Intellectual Capital, 5(3), 426-442. https://doi.org/10.1108/14691930410550381

Medsker, G. (1994). A review of current practices for evaluating causal models in organizational behavior and human resources management research. Journal of Management, 20(2), 439-464. https://doi.org/10.1016/0149-2063(94)90022-1

Meissner, P., \& Wulf, T. (2014). Antecendents and effects of decision comprehensiveness: The role of decision quality and perceived uncertainty. European Management Journal, 32(4), 625-635. https://doi.org/10.1016/j.emj.2013.10.006

Milliken, F. J. (1987). Three Types of Perceived Uncertainty about the Environment: State, Effect, and Response Uncertainty. Academy of Management Review, 12(1), 133-143.

Mondal, A., Kumar Ghosh, S., Mondal Santanu Kumar Ghosh, A., Joshi, M., Cahill, D., Sidhu, J., \& Kansal, M. (2012). Intellectual capital and financial performance of Indian banks. Article in Journal of Intellectual Capital, 13, 132-151. https://doi.org/10.1108/14691931211276115

Mtawa, N. N., Fongwa, S. N., \& Wangenge-Ouma, G. (2016). The scholarship of university-community engagement: Interrogating Boyer's model. International Journal of Educational Development, 49(April), 126-133. https://doi.org/10.1016/j.ijedudev.2016.01.007

Muhammad, S. (2016). Pentingnya Pengembangan Budaya Organisasi pada Perguruan Tinggi. Jurnal Ilmiah Widya, 4(April), 1-23.

Murias, P., de Miguel, J. C., \& Rodríguez, D. (2008). A composite indicator for university quality assesment: The case of Spanish higher education system. Social Indicators Research, 89(1), 129-146. https://doi.org/10.1007/s11205-007-9226-z

Nir, A. E., \& Sharma Kafle, B. (2013). The effect of political stability on public education quality. International Journal of Educational Management, 27(2), 110126. https://doi.org/10.1108/09513541311297487 
Nugroho, L., Hidayah, N., Badawi, A., \& Mastur, A. A. (2020). The urgency of Leadership in Islamic Banking Industries Performance. In The 1st Annual Conference Economics, Business, and Social Sciences (pp. 1-7). https://doi.org/10.4108/eai.263-2019.2290681

Nugroho, L., Husnadi, T. C., Utami, W., \& Hidayah, N. (2017). Maslahah and Strategy to Establish a Single State-Owned Islamic Bank in Indonesia. Tazkia Islamic Finance and Business Review, 10(1), 1-17.

Paoloni, P., Cesaroni, F. M., \& Demartini, P. (2019). Relational capital and knowledge transfer in universities. Business Process Management Journal, 25(1), 185-201. https://doi.org/10.1108/BPMJ-06-2017-0155

Rad, A. M. M. (2006). The impact of organizational culture on the successful implementation of total quality management. TQM Magazine, 18(6), 606-625. https://doi.org/10.1108/09544780610707101

Rahayu, Y. S. (2011). Kualitas Jasa Dan Kepuasan Mahasiswa Perguruan Tinggi Swasta Di Malang. Iqtishoduna, 3(2). https://doi.org/10.18860/iq.v3i2.250

Ramírez, Y., \& Gordillo, S. (2014). Recognition and measurement of intellectual capital in Spanish universities. Journal of Intellectual Capital, 15(1), 173-188. https://doi.org/10.1108/JIC-05-2013-0058

Secundo, G., De Beer, C., Schutte, C. S. L., \& Passiante, G. (2017). Mobilising intellectual capital to improve European universities' competitiveness: The technology transfer offices' role. Journal of Intellectual Capital, 18(3), 607-624. https://doi.org/10.1108/JIC-12-2016-0139

Stephen M. Nowlis, \& Simonson, I. (1996). The Effect of New Product Features on Brand Choice. Academy of Management Review, 33(1), 36-46.

Sudirman, A. (Acai ), Alaydrus, S. (Syafika), Rosmayati, S. (Siti), Syamsuriansyah, S. (Syamsuriansyah), Nugroho, L. (Lucky), Arifudin, O. (Opan), ... Rijal, K. (Khairul). (2020). Perilaku Konsumen Dan Perkembangannya Di Era Digital. Widina Bhakti Persada Bandung. Retrieved from www.penerbitwidina.com

Sukmana, Y., \& Jatmiko, B. P. (2019). Sri Mulyani: Anggaran Pendidikan 20 Persen dari APBN Hasilnya Tak Memuaskan... Retrieved March 17, 2021, from https://money.kompas.com/read/2019/08/09/162702626/sri-mulyani-anggaranpendidikan-20-persen-dari-apbn-hasilnya-tak-memuaskan

Utami, W., Nugroho, L., Mappanyuki, R., \& Yelvionita, V. (2020). Early Warning Fraud Determinants In Banking Industries. Asian Economic and Financial Review, 10(6), 604-627. https://doi.org/10.18488/journal.aefr.2020.106.604.627

Utami, W., Wahyuni, P. D., \& Nugroho, L. (2020). Determinants of Stock Liquidity: 
Hidayaha, N., Nugrohob L. \& Prihantoc H. (2021). Human Capital and Relational Capital on University Quality with Environmental Uncertainty as Moderating Variables (Evidence in Java Island-Indonesia), BILTURK, The Journal of Economics and Related Studies, 3(3), 164-182. . doi: 10.47103/bilturk.908864.

Forward-Looking Information, Corporate Governance, and Asymmetric Information. Journal of Asian Finance, Economics and Business, 7(12), 795-807. https://doi.org/10.13106/JAFEB.2020.VOL7.NO12.795

Vodenko, K. V., \& Lyausheva, S. A. (2020). Science and education in the form 4.0: public policy and organization based on human and artificial intellectual capital. Journal of Intellectual Capital, 21(4), 549-564. https://doi.org/10.1108/JIC-112019-0274

Wahyudin, D., \& Suwirta, A. (2020). Politics of Curriculum in the Educational System in Indonesia. Tawarikh, 11(April), 143-158. Retrieved from http://www.journals.mindamas.com/index.php/tawarikh/article/view/1307

Wang, X., Shi, H., \& Zhang, Q. (2017). Dynamic Capability and Path Dependent. In 2nd International Seminar on Education Innovation and Economic Management (Vol. 156, pp. 346-350).

Zhou, C. (2008). Emergence of the entrepreneurial university in evolution of the triple helix. Journal of Technology Management in China, 3(1), 109-126. https://doi.org/10.1108/17468770810851539 